\title{
Relokasi Hiposenter Gempabumi Donggala Tahun 2018 Menggunakan Metode Hyporelocate
}

\author{
Sigit Eko Kurniawan ${ }^{\left.1^{*}\right)}$, Febriani Saputri ${ }^{2}$ \\ ${ }^{1}$ BMKG Stasiun Geofisika Padang Panjang. Padang \\ ${ }^{2}$ BMKG Stasiun Geofisika Manado, Manado \\ ${ }^{*}$ E-mail: sigitekokurniawan@yahoo.com
}

\begin{abstract}
ABSTRAK
Pada Jumat, 28 September 2018, pukul 17.02.44 WIB terjadi gempabumi yang berpotensi tsunami di daerah Donggala. BMKG mengeluarkan parameter gempabumi dengan magnitudo 7.7, lokasi 0.18 LS dan 119.85BT atau $26 \mathrm{~km}$ dari Utara Donggala. Gempabumi dengan kedalaman $10 \mathrm{~km}$ tersebut terjadi dengan mekanisme sesar mendatar akibat aktivitas sesar Palu-Koro dan diikuti oleh ratusan gempabumi susulan. Sesar Palu-Koro melintang dari Selat Makasar sampai pantai utara Teluk Bone memotong jantung kota Palu hingga ke sungai Lariang, Donggala. Studi ini akan merelokasi hiposenter gempabumi Donggala beserta gempabumi pendahulu dan susulannya menggunakan metode hypoRelocate. Relokasi ini menggunakan waktu tempuh mutlak dari 599 gempabumi, beda waktu tempuh relatif dari 2.492 pasangan gempabumi dan waktu dari 11 tumpukan coda cross-correlogram untuk selanjutnya diinversi dengan simulated annealing. Metode ini memiliki kelebihan berupa berupa pengurangan ketergantungan hasil relokasi pada lokasi absolut katalog dengan menyisir waktu tempuh mutlak, pembatasan jarak relatif antargempabumi dengan menggunakan perbedaan waktu tempuh dan koreksi jarak antargempabumi berdasarkan tumpukan coda cross-correlogram. Hasil relokasi menunjukan episenter gempabumi lebih mengumpul atau terfokus daripada posisi awal dan membentuk kluster yang berwujud sebuah bidang dengan luas sekitar $250 \mathrm{~km} \times 85 \mathrm{~km}$. Sebagian besar episenter setelah direlokasi bergeser dengan jarak 15-20 km dan perubahan kedalaman gempabumi dominan kurang dari $10 \mathrm{~km}$. Arah pergeseran episenter tersebar merata secara acak namun arah barat lebih sedikit dominan. Relokasi menggunakan hypoRelocate menunjukkan peningkatan kualitas yang cukup baik dengan turunnya nilai total residual setelah relokasi. Hasil validasi relokasi hypoRelocate dengan peta citra satelit ALOS-2 mode ScanSAR dan ALOS-2 PALSAR-2 menunjukan bahwa hasil relokasi berada pada bidang sesar akibat gempabumi.
\end{abstract}

Kata kunci: Hiposenter Gempabumi Donggala, Relokasi hiposenter, Hyperelocate,

\section{ABSTRACT}

On Friday, September 28th 2018 at 17.02.44 WIB, a large earthquake that has the potential to cause a tsunami occurs in the Donggala area. BMKG release the earthquake parameters with magnitude 7.7, location 0.18 LS and 119.85BT or $26 \mathrm{~km}$ from the North Donggala Central Sulawesi. Earthquake that has depth $10 \mathrm{~km}$ was clarified as a strike slip fault mechanism due to the Palu-Koro fault activity and followed by a hundreds of aftershocks. The Palu-Koro fault crossing from the Makassar Strait to the northern coast of Bone Bay cuts the heart of Palu city to the Lariang River, Donggala. This study will relocate Donggala earthquake both foreshock, mainshock and aftershock using the Hyporelocate method. This relocation uses the absolute travel time of 599 earthquakes, the relative travel time of 2492 earthquake pairs and 11 time coda cross-correlogram which are inverted with simulated annealing. This method has the advantage by reducing reliance on relocation results in absolute catalog locations by combing absolute travel time, resticting the relative distance between earthquakes based on differencial travel time of earthquake pairs, and of inter-earthquake distance correction based on stacking coda cross-correlogram. The results of relocation show that earthquake epicenter was more collected or focused than the initial position and formed a cluster in the form of a field with an area of about $250 \mathrm{~km}$ $\times 85 \mathrm{~km}$. Most of the epicenter after being relocated shifted with a distance of 15-20 km and the change in the depth of the dominant earthquake was less than $10 \mathrm{~km}$. The direction of shifting the epicenter is spread evenly at random but the west is less dominant. Relocation using hypoRelocate showed a good improvement in quality with a decrease in total residual values after relocationThe results of the validation of hypoRelocate relocation with maps of ALOS-2 mode ScanSAR and ALOS-2 PALSAR-2 satellite images show that the results of the relocation are in the plane of the fault moving due to the main earthquake.

Keywords:Donggala Earthquake, Earthquake relocation, Hyperelocate 


\section{PENDAHULUAN}

Hari Jumat, 28 September 2018, pukul 17:02:44 WIB terjadi gempabumi yang berpotensi tsunami di daerah Donggala, Sulawesi Tengah. Badan Meteorologi Klimatologi dan Geofisika(BMKG) mengeluarkan parameter gempabumi dengan magnitudo 7,7 dan berlokasi pda $0,18^{\circ} \mathrm{LS}$, $119,85^{\circ} \mathrm{BT}$ atau $26 \mathrm{~km}$ dari Utara Kabupaten Donggala, dengan kedalaman $10 \mathrm{~km}$. Gempabumi tersebut diikuti ratusan gempabumi susulan dengan magnitudo yang bervariasi. Hasil analisis BMKG menunjukkan mekanisme sumber dari gempabumi tersebut adalah aktifitas dari struktur sesar mendatar Palu-Koro. Berdasarkan hasil laporan masyarakat, guncangan kuat dirasakan di Kota Palu, Mapaga, Gorontalo, Poso, Majene, Toraja, Soroako, Kendari, Kolaka, Konawe Utara, Bone, Sengkang, Kalimantan Timur, Kalimantan Utara, Makassar,dan Gowa. Gempabumi juga menyebabkan kerusakan pada bangunan dan berbagai infrastruktur serta ribuan orang meninggal dan luka-luka akibat efek sekunder dari gempabumi tersebut.

Daerah Sulawesi Tengah, khususnya Donggala merupakan wilayah tektonik aktif di Indonesia dengan aktivitas kegempaan yang tinggi. Gempabumi di daerah ini digolongkan menjadi gempabumi dangkal yang diakibatkan oleh keberadaan sesar. Sesar tersebut adalah sesar Palu Koro yang merupakan struktur utama Pulau Sulawesi serta merupakan sesar terpanjang yang ada di pulau tersebut. Sesar tersebut memanjang dari Selat Makasar sampai pantai utara Teluk Bone memotong jantung kota Palu hingga ke sungai Lariang, Donggala. Berdasarkan hasil perhitungan terkini, nilai slip rate (laju geser) sesar Palu Koro berkisar 33 $\mathrm{mm} /$ tahun. Sesar Palu Koro terdiri dari empat segmen sesar, yaitu segmen Makassar Strait, Mou, Saluki, dan Moa. Segmen Makassar Strait menjadi segmen yang paling panjang dalam sesar ini.

Salah satu parameter gempabumi yang penting adalah penentuan hiposenter. Penentuan hiposenter sangat bermanfaat pada studi proses dan evolusi mekanisme sumber dari gempabumi besar, validasi variasi kecepatan gelombang, dan studi struktur zona patahan. Manfaat tersebut membuat penentuan hiposenter yang akurat menjadi kebutuhan mutlak untuk analisis kegempaan lanjutan. Teknik relokasi gempabumi yang baik dibutuhkan untuk menghasilkan lokasi hiposenter gempa yang akurat.

Teknik relokasi hiposenter gempabumi telah banyak mengalami perkembangan. Salah satunya teknik relokasi hiposenter adalah metode hypoRelocate. hypoRelocate merupakan metode yang dikembangkan oleh Sun dkk.(2016). Metode ini menggabungkan permasalahan waktu tempuh mutlak, perbedaan waktu tempuh relatif, dan penambahan permasalahan baru berupa waktu puncak lonjakan pada pada tumpukan coda crosscorrelogram yang kemudian diinversi bersama menggunakan simulated annealing. Kelebihan dalam metode ini berupa pengurangan ketergantungan hasil relokasi pada lokasi absolut katalog dengan menyisir waktu tempuh mutlak, pembatasan jarak relatif antargempabumi dengan menggunakan perbedaan waktu tempuh dan koreksi jarak antargempabumi berdasarkan tumpukan coda cross-correlogram. Metode ini telah digunakan untuk merelokasi gempabumi Lushan (2013), Pidie Jaya (2016), dan Jiuzhaigou (2017).

Kebaruan dalam metode hypoRelocate adalah penambahan tumpukan coda cross-correlogram. Tumpukan coda cross-correlogram merupakan hasil aplikasi seismik interferometri dalam seismologi gempabumi. Coda adalah rangkaian gelombang komplek yang datang setelah gelombang langsung akibat pengaruh heterogenitas di litosfer bumi. Coda dicacah dan dikorelasi-silangkan dan kemudian hasilnya ditumpuk sehingga menjadi tumpukan coda cross-correlogram. Tumpukan coda crosscorrelogram akan mengandung fungsi green yang setara dari semua gelombang geser yang menjalar di antara dua sumber seismik. Fungsi green tersebut digunakan sebagai permasalahan dalam metode relokasi hypoRelocate.

Inversi Simulated annealing digunakan dalam hypoRelocate karena permasalahan dalam relokasi dan beberapa parameter model tidak memiliki ketergantungan linier pada fungsi tujuan. Simulated annealing merupakan metode pencarian acak terarah yang dikenalkan oleh Kirkpatrick, Gelatt, dan Vecchi (1983). Inversi ini dapat memberi gambaran keseluruhan bentuk permukaan fungsi objektif karena dilakukan pencarian secara global. Pencarian solusi dalam 
dalam inversi ini dapat diarahkan dengan pemilihan model yang dimodifikasi mendekati daerah dengan probabilitas yang besar.

Dalam studi ini, penulis akan merelokasi hiposenter gempabumi Donggala tahun 2018 dengan menggunakan metode hypoRelocate.

\section{METODE}

Penelitian dilakukan pada daerah Sulawesi Tengah pada koordinat $1,76^{\circ} \mathrm{S}-0,65^{\circ} \mathrm{N}$ dan $118,97 \mathrm{BT}-121,15^{\circ} \mathrm{BT}$. Data yang digunakan berasal dari katalog BMKG dari tanggal 24 September 2018 s.d. 3 November 2018. Dalam rentang waktu tersebut terdapat 599 gempabumi. Stasiun pengamatan yang digunakan sebanyak 21 stasiun InaTEWS dengan jarak maksimal 5 derajat dari episenter gempabumi utama Donggala. Model referensi kecepatan gelombang $\mathrm{P}$ dan gelombang $\mathrm{S}$ menggunakan model kecepatan dari IASP91 (Tabel 1).

Tabel 1. Model kecepatan IASP91

\begin{tabular}{|c|c|c|c|}
\hline Lapisan & Kedalaman $(\mathrm{km})$ & $\mathrm{Vp}(\mathrm{km} / \mathrm{s})$ & $\mathrm{Vs}(\mathrm{km} / \mathrm{s})$ \\
\hline 1 & $0-20$ & 5.8 & 3.36 \\
\hline 2 & $20-35$ & 6.5 & 3.75 \\
\hline 3 & $35-71$ & 8.04 & 4.47 \\
\hline 4 & $71-120$ & 8.05 & 4.5 \\
\hline
\end{tabular}

Langkah - langkah untuk melakukan relokasi hiposenter menggunakan metode hypoRelocate dijelaskan berikut ini.

\section{Menghitung waktu mutlak gempabumi}

Waktu mutlak gempabumi adalah perbedaan waktu antara waktu tiba gelombang dengan waktu terjadinya gempabumi (origin time). Waktu tiba didapatkan dari hasil pencuplikan fase gelombang gelombang $\mathrm{P}$ dan fase gelombang S dari 599 gempabumi. Data waktu tiba yang digunakan untuk inversi meliputi data waktu tiba gelombang $\mathrm{P}$ dan data waktu tiba gelombang S sebanyak 7.202 fase.

\section{Menghitung beda waktu tempuh relatif}

Penentuan beda waktu tempuh antargempabumi diawali dengan memasangkan pasangan gempabumi dengan jarak kurang dari $20 \mathrm{~km}$ sesuai dengan data katalog. Ketika ada 2 sumber gempa dengan jarak antar sumber lebih kecil daripada jarak kedua sumber terhadap suatu stasiun, maka lintasan kedua sumber gempa tersebut dianggap sama. Sehingga perbedaan nilai waktu tempuh antar keduanya yang terekam di suatu stasiun dianggap sebagai fungsi jarak antara kedua jarak sumber gempa. Hasil pemasangan gempabumi didapatkan 2.492 pasangan gempabumi dengan data perbedaan waktu tiba gelombang $\mathrm{P}$ sebanyak 14.513 dan data perbedaan waktu tiba gelombang $S$ sebanyak 1.038 dari data katalog.

3. Membuat tumpukan korelasi silang gelombang coda

Sumber tumpukan korelasi silang coda berasal dari sinyal 131 gempabumi referensi dengan magnitudo di atas 4,5 pada 21 stasiun pengamatan. Pembuatan tumpukan coda dimulai dari rotasi sinyal ke arah tangensial, filter bandpass $0,5-5,0 \mathrm{~Hz}$, dan menggeser 13 kali jendela waktu sebanyak 10 detik dimulai dari 10 detik setelah perkiraan kedatangan gelombang $\mathrm{S}$ sampai 40 detik setelahnya. Korelasi silang dilakukan untuk setiap stasiun dan setiap jendela waktu antargempabumi, dan korelasi silang dari semua stasiun ditumpuk untuk setiap jendela waktu. Dari 131 gempabumi dihasilkan 152 tumpukan coda cross-correlogram. Dari jumlah tersebut, hanya 11 tumpukan coda crosscorrelogram yang menunjukan lonjakan yang jelas. Sun dkk. (2016) mengilustrasikan ketidakmunculan spike dalam tumpukan coda cross-correlogram di antaranya disebabkan oleh heterogenitas hamburan seismik, jenis mekanisme fokus pasangan gempabumi, jumlah dan cakupan stasiun pengamatan, orientasi relatif antarsumber gempabumi, dan bising seismik.

\section{Melakukan inversi simulated annealing}

Hasil dari langkah 1-3 yakni waktu tempuh mutlak gempabumi, beda waktu tempuh relatif pasangan gempabumi dan waktu pucak lonjakan dari tumpukan korelasi silang coda selanjutnya diinversi dengan simulated annealing. Pemanfaatan inversi dengan simulated annealing untuk mencari hiposenter terbaik dan origin time gempabumi berdasarkan total residu minimal dari semua gempabumi yang ditentukan oleh perbedaan antara hasil pengamatan dan perhitungan dari tiga permasalahan yang ada.

Berikut ini adalah persamaan total residu dalam perhitungan hyporelocate 


$$
\begin{gathered}
\Delta T^{r e s}=w_{1} * \sum_{i}^{N} \frac{\Delta T_{i, a}}{N}+w_{2} * \sum_{i, j}^{M} \frac{\Delta T_{i, j, r}}{M}+ \\
w_{3} * \sum_{i, j}^{Q} \frac{\Delta T_{i, j, c}}{Q}
\end{gathered}
$$

di mana

$\Delta \mathrm{T}_{\mathrm{i}, \mathrm{a}}=$ residual waktu mutlak dari gempabumi $\mathrm{i}$, $\Delta \mathrm{T}_{\mathrm{i}, \mathrm{j}, \mathrm{r}}=$ residual perbedaan waktu tempuh antara pasangan gempabumi $\mathrm{i}, \mathrm{j}$,

$\Delta \mathrm{T}_{\mathrm{i}, \mathrm{j}, \mathrm{c}}=$ residual waktu tumpukan coda crosscorrelogram antara pasangan gempabumi i, $\mathrm{j}$,

$\mathrm{N}=$ jumlah total gempabumi,

$\mathrm{M}=$ jumlah pasangan gempabumi dengan data perbedaan waktu tempuh,

$\mathrm{Q}=$ jumlah pasangan tumpukan coda crosscorrelogram,

$w_{1}, w_{2}$, dan $w_{3}\left(w_{1}+w_{2}+w_{3}=1\right)=$ faktor pembobotan

Prosedur metode hypoRelocate diilustrasikan secara skematis pada Gambar 1

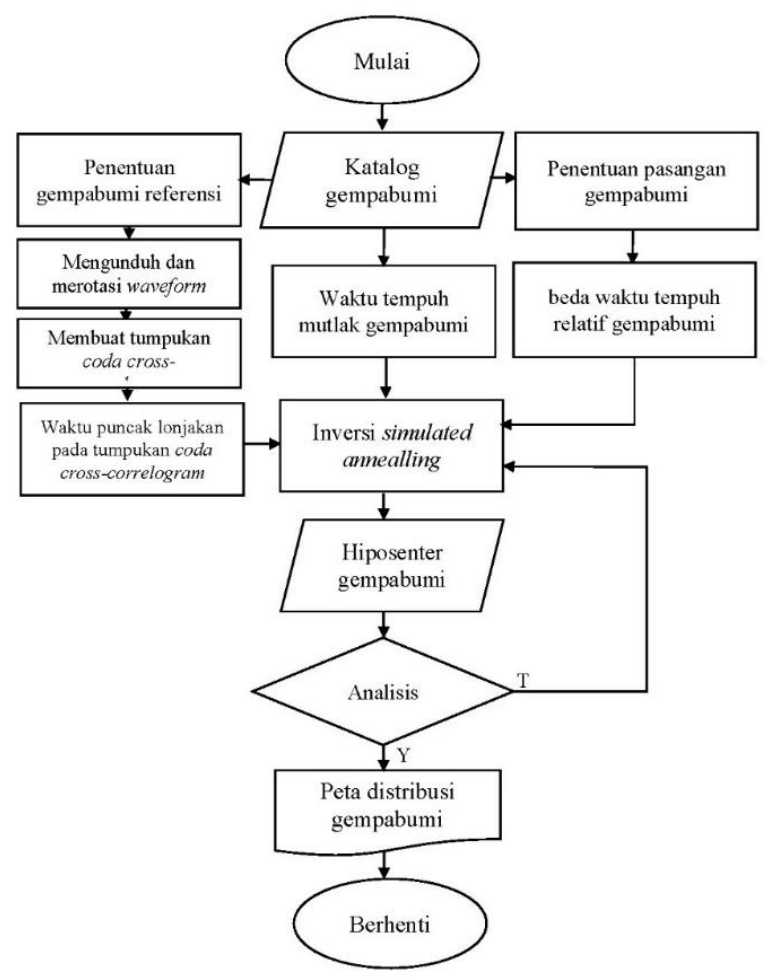

Gambar 1. Prosedur metode hypoRelocate

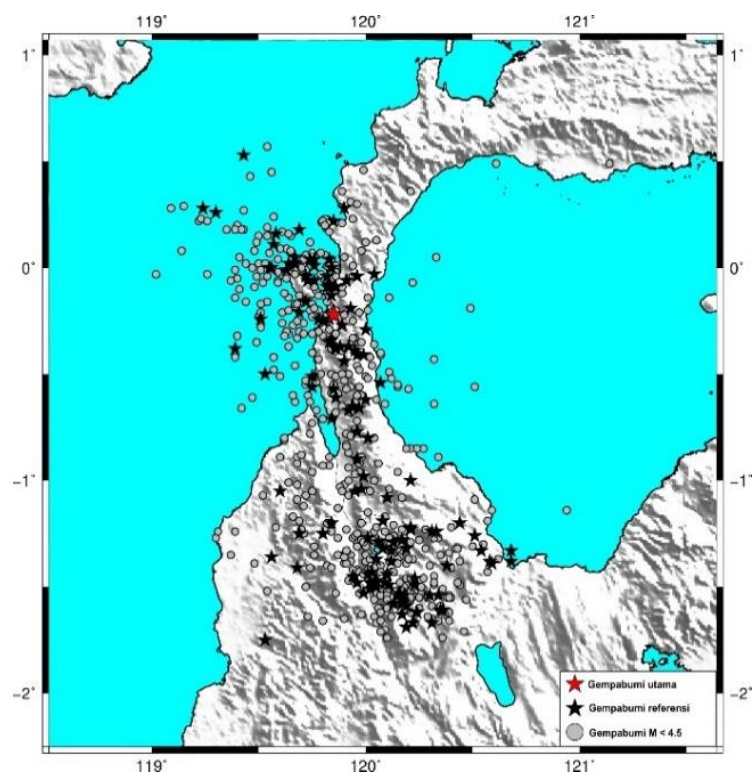

(a)

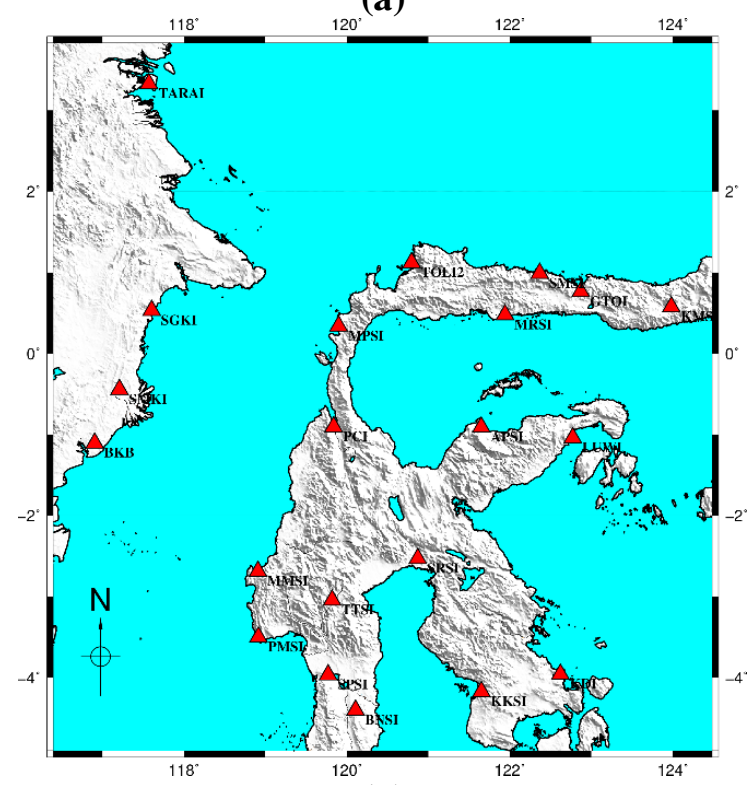

(b)

Gambar 2. (a) Hiposenter gempabumi sebelum direlokasi, (b) Stasiun pengamatan yang digunakan dalam relokasi(segitiga merah).

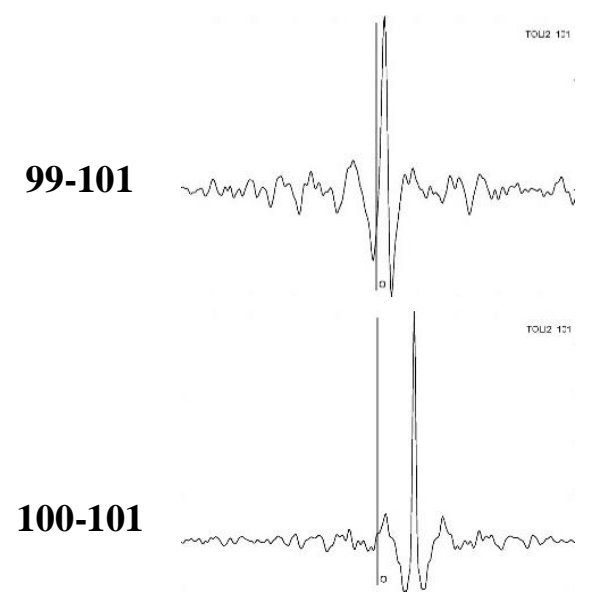



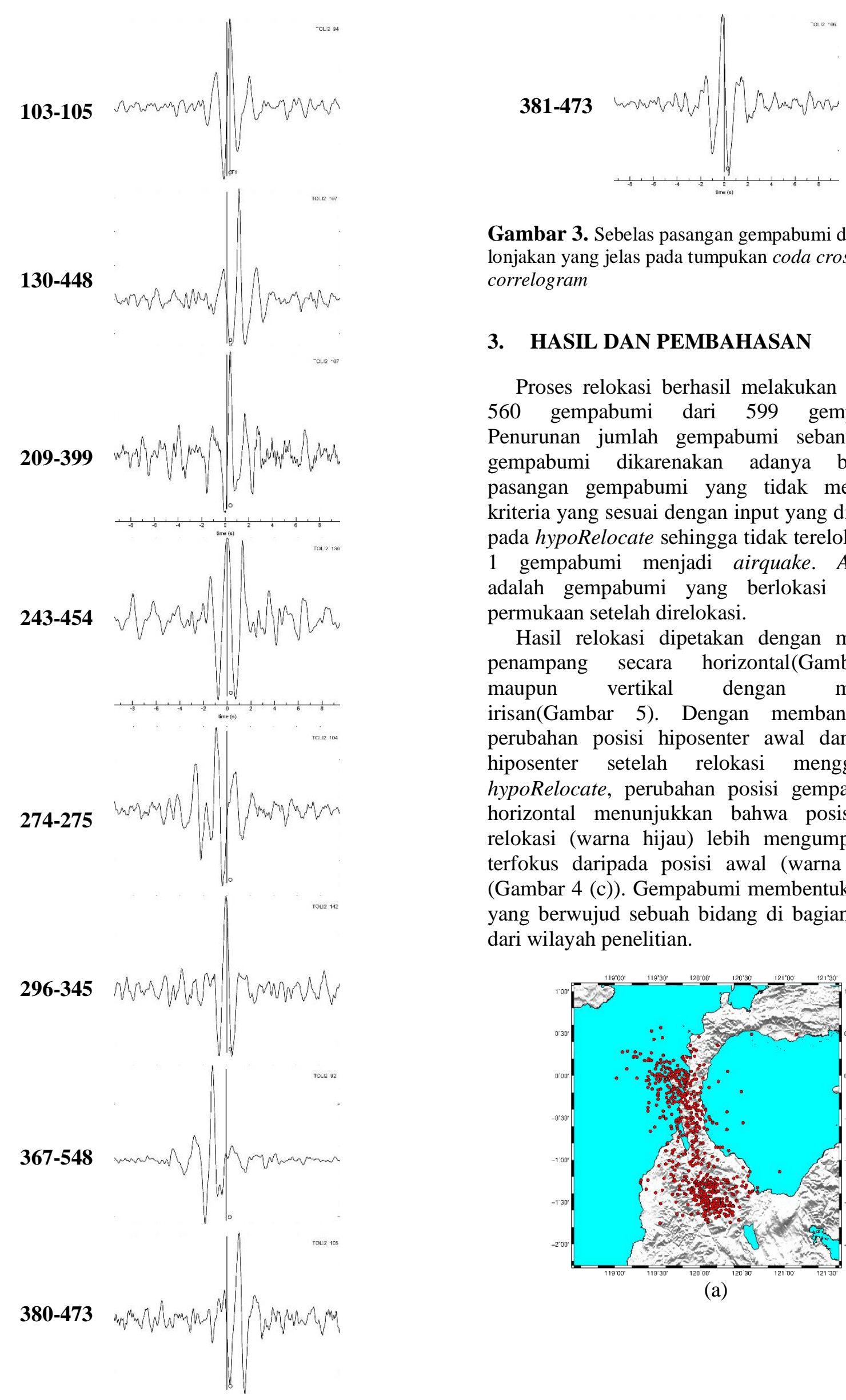

Gambar 3. Sebelas pasangan gempabumi dengan lonjakan yang jelas pada tumpukan coda crosscorrelogram

\section{HASIL DAN PEMBAHASAN}

Proses relokasi berhasil melakukan relokasi 560 gempabumi dari 599 gempabumi. Penurunan jumlah gempabumi sebanyak 39 gempabumi dikarenakan adanya beberapa pasangan gempabumi yang tidak memenuhi kriteria yang sesuai dengan input yang diberikan pada hypoRelocate sehingga tidak terelokasi dan 1 gempabumi menjadi airquake. Airquake adalah gempabumi yang berlokasi di atas permukaan setelah direlokasi.

Hasil relokasi dipetakan dengan membuat penampang secara horizontal(Gambar 4) maupun vertikal dengan membuat irisan(Gambar 5). Dengan membandingkan perubahan posisi hiposenter awal dan posisi hiposenter setelah relokasi menggunakan hypoRelocate, perubahan posisi gempa secara horizontal menunjukkan bahwa posisi hasil relokasi (warna hijau) lebih mengumpul atau terfokus daripada posisi awal (warna merah) (Gambar 4 (c)). Gempabumi membentuk kluster yang berwujud sebuah bidang di bagian tengah dari wilayah penelitian.

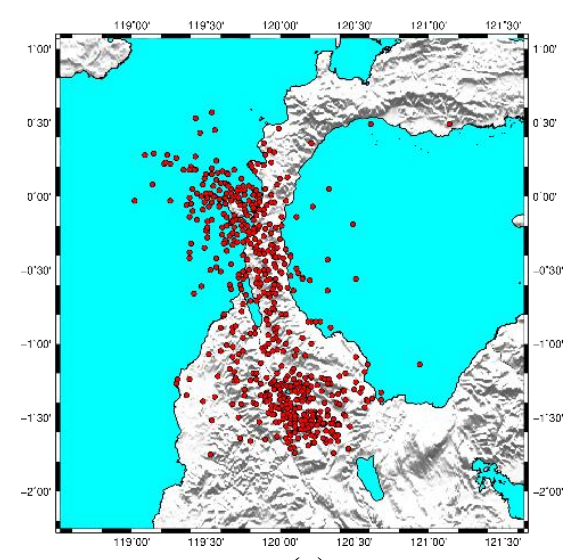

(a) 


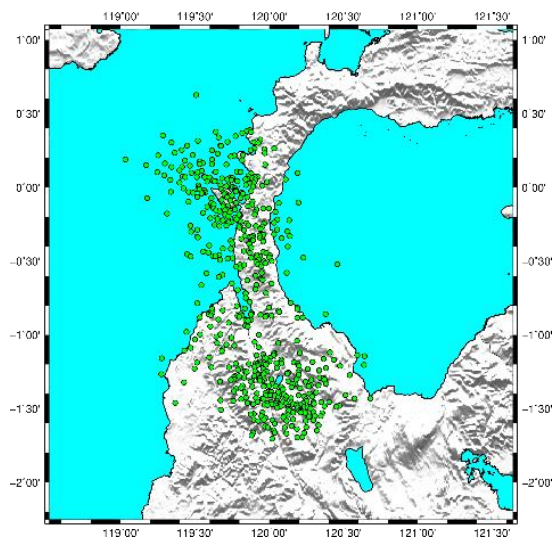

(b)

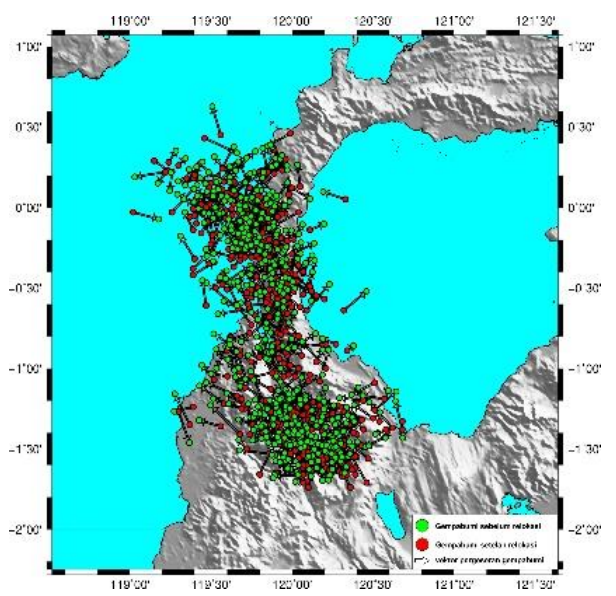

(c)

Gambar 4. (a) Penampang horizontal gempabumi sebelum direlokasi, (b) setelah direlokasi , (c) dan perbandingan sebelum dan setelah direlokasi

Pada penampang vertikal dibuat irisan A-A' yang merupakan irisan searah strike sesar dan irisan B-B' yang merupakan irisan tegak lurus terhadap strike sesar untuk melihat pola sebaran kedalaman gempabumi baik sebelum dan sesudah relokasi.

Pada segmen irisan A - A', terlihat bahwa setelah direlokasi membentuk sebuah bidang dengan panjang patahan berkisar $250 \mathrm{~km}$. Dari segi kedalaman tampak perubahan kedalaman yang signifikan. Relokasi mampu memperbaiki kedalaman tetap $10 \mathrm{~km}$ menjadi kedalaman gempabumi yang diakibatkan oleh sesar Palu Koro. Dalam periode 2009-2015, kedalaman gempabumi akibat sesar Palu Koro adalah 40 $\mathrm{km}^{1}$.

Pada segmen irisan B - B', terlihat bahwa setelah direlokasi membentuk sebuah bidang dengan lebar patahan berkisar $85 \mathrm{~km}$. Pola sebaran kedalaman tampak menunjukan hasil yang sama dengan irisan A-A'. Gempabumi dengan kedalaman awal $10 \mathrm{~km}$ mengalami pergeseran kedalaman dengan acak. Dari irisan
A-A' dan B-B', bidang sesar yang mengalami pergerakan diperkirakan sebesar $250 \mathrm{~km} \times 85$ $\mathrm{km}$.

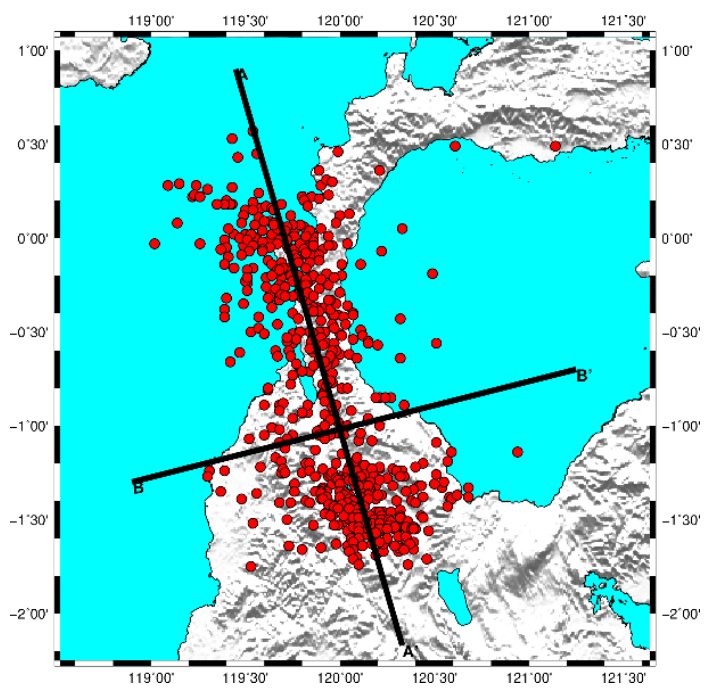

(a)

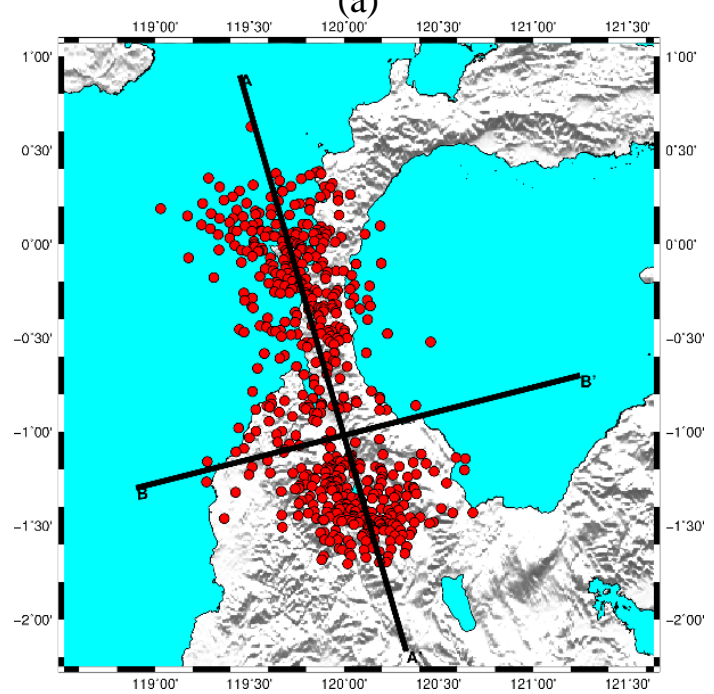

(b)

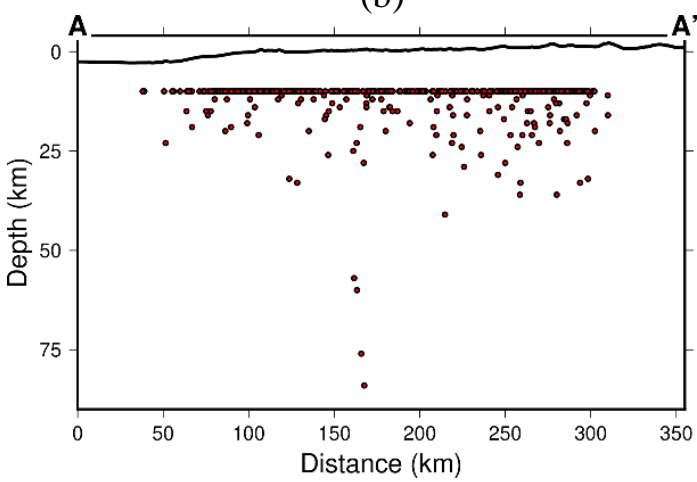

(c) 


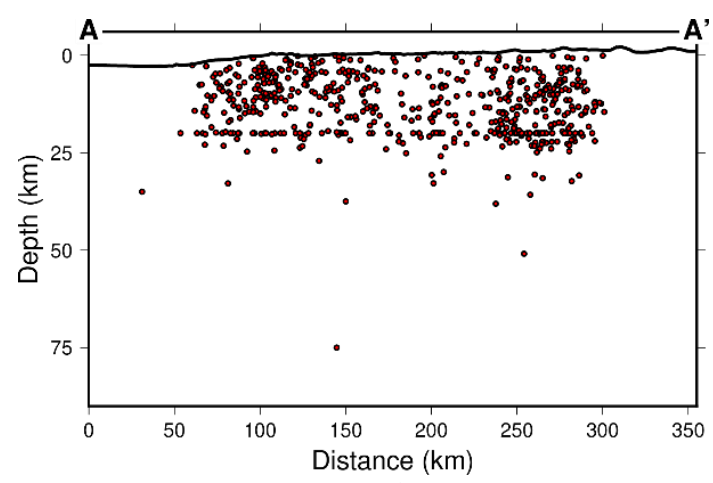

(d)

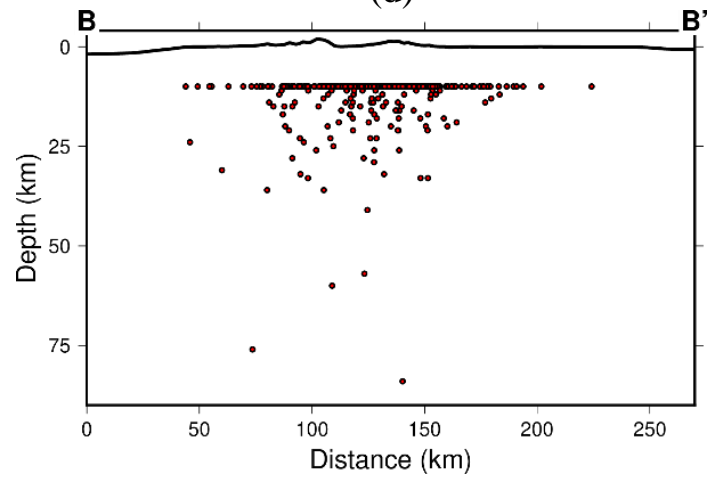

(e)

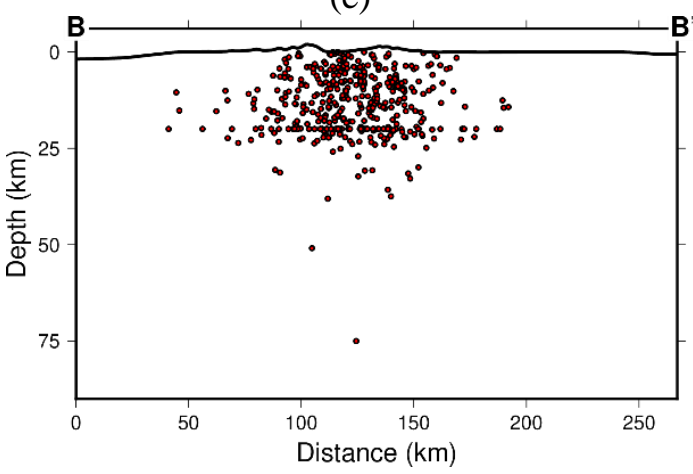

(f)

Gambar 5. (a) dan (b) irisan A-A' dan B-B' pada peta sebelum dan sesudah relokasi, (c) dan (d) irisan penampang vertikal A-A' sebelum dan sesudah relokasi , (e) setelah relokasi, (f) penampang vertikal irisan B-B' sebelum relokasi, (d) setelah relokasi.

Besarnya pergeseran dan arah episenter setelah relokasi ditunjukan oleh diagram rose dan diagram kompas(Gambar 6). Sebagian besar episenter bergeser pada jarak antara 15-20 km. Pergeseran maksimum dalam relokasi gempabumi Donggala sebesar 30,76 km, sedangkan pergeseran minimum sebesar 435 meter. Pergeseran maskimun ini hanya terjadi pada satu gempabumi. Arah pergeseran posisi gempa tersebar secara acak ke segala arah, namun dominan terjadi pada arah barat .

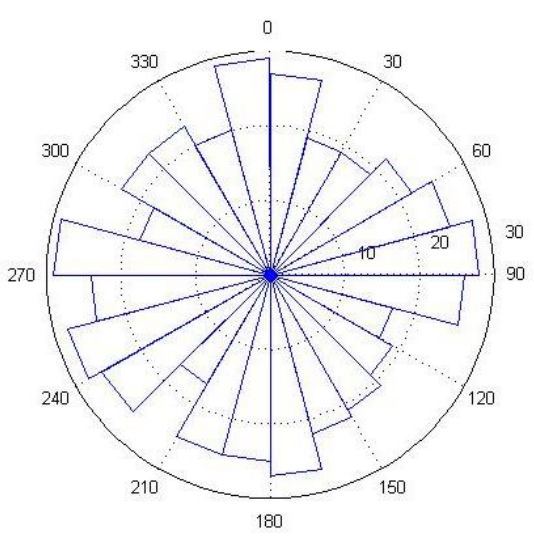

(a)

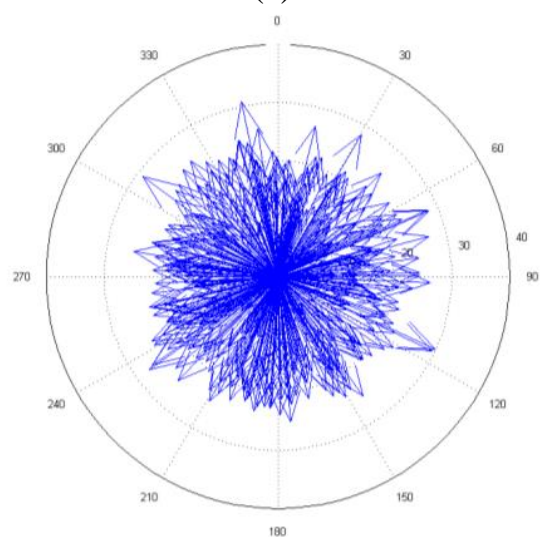

(b)

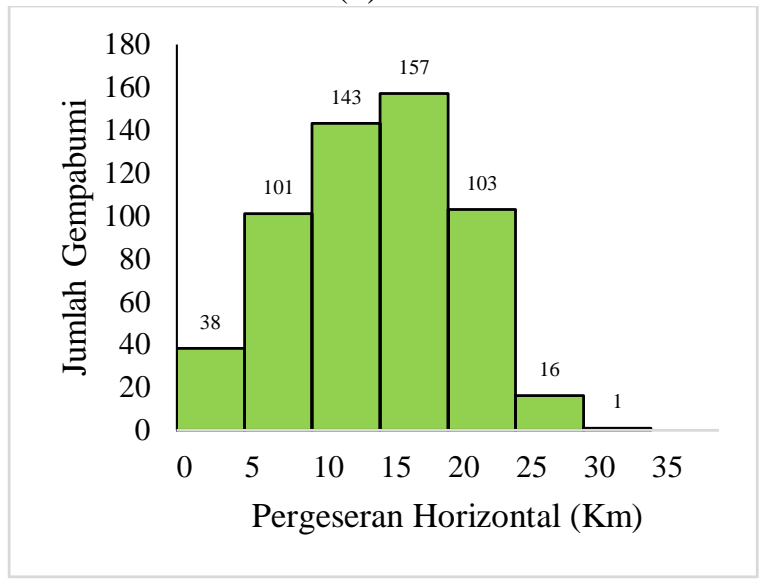

(c)

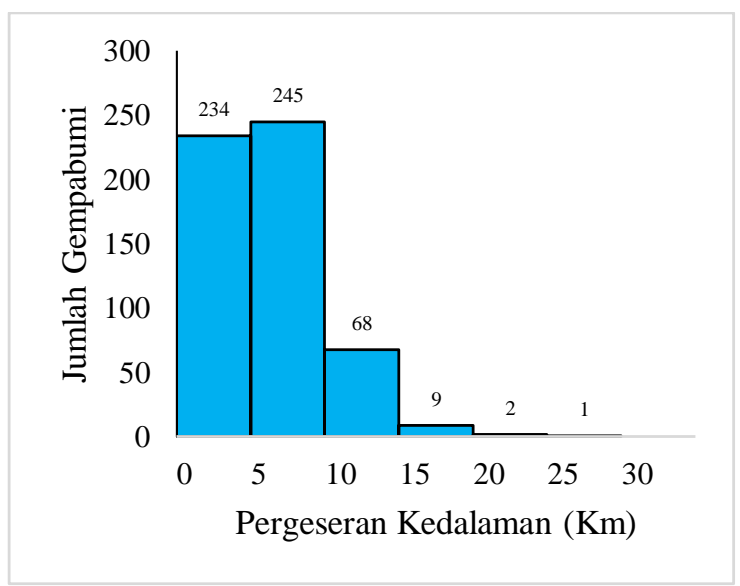


(d)

Gambar 6. (a) diagram rose, (b) diagram kompas , (c) histogram pergeseran episenter horizontal, dan (d) histogram pergeseran kedalaman.

Besarnya distribusi perubahan kedalaman gempabumi setelah direlokasi digambarkan histogram pada Gambar 6 (d). Nilai perubahan kedalaman terbesar adalah $25,56 \mathrm{~km}$. Sebagian besar gempabumi mengalami perubahan pada skala kecil. Dua ratus tiga puluh empat gempabumi mengalami pergeseran antara 0-5 $\mathrm{km}$, dilanjutkan dengan jumlah terbesar yakni 245 gempabumi mengalami pergeseran kedalaman senilai $5-10 \mathrm{~km}$. Sebagian kecil lainnya mengalami pergeseran kedalaman yang cukup besar antara lain 68 gempabumi bergeser antara $10-15 \mathrm{~km}, 9$ gempabumi mengalami pergeseran kedalaman senilai $15-20 \mathrm{~km}, 2$ gempabumi berada pada rentang pergeseran 20$25 \mathrm{~km}$ dan 1 gempabumi dengan nilai terbesar memiliki pergeseran lebih dari $25 \mathrm{~km}$.

Setelah dilakukan relokasi, nilai residual total mulai berkurang. Hal tersebut ditunjukan pada gambar 7 yang memperlihatkan histogram residual total dari katalog BMKG sebelum dan setelah dilakukan relokasi. Dari kedua histogram tersebut nampak bahwa nilai-nilai residual total setelah dilakukan relokasi lebih banyak yang mendekati nol dibandingkan sebelum dilakukan relokasi. Nilai residual total yang menurun, menunjukan hasil relokasi hiposenter gempabumi dengan memanfaatkan hypoRelocate dapat memberikan nilai residual yang lebih baik.

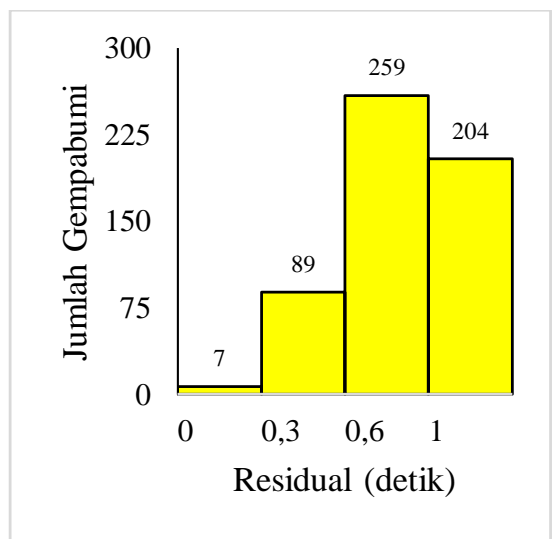

(a)

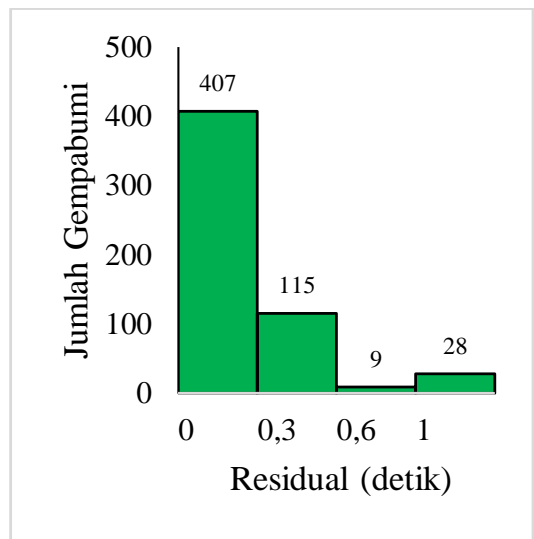

(b)

Gambar 7. (a) Histogram residual awal, (b) histogram residual sesudah relokasi

Hasil relokasi dari hypoRelocate dilakukan validasi terhadap peta perpindahan koseismik hasil citra satelit Advanced Land Observing Satellite-2 (ALOS-2) mode ScanSAR oleh JAXA $^{10}$ dan perpindahan horizontal hasil citra satelit Advanced Land Observing Satellite-2 (ALOS-2) PALSAR-2 oleh JAXA ${ }^{11}$. Hasil pencocokan menunjukan bahwa lokasi episenter hasil relokasi berada pada bidang sesar yang bergerak akibat gempabumi. Gempabumi utama memicu tegangan utama pada sistem yang kompleks akibat pergeseran tiba-tiba. Kawasan zona rupture memerlukan penyesuaian kembali menuju keadaan baru sehingga menghasilkan gempabumi susulan. Pada gambar 8 tampak bahwa distribusi gempabumi susulan memanjang dengan pola yang searah dengan jurus sesar. Hasil tersebut menandakan bahwa relokasi dengan hypoRelocate sudah cukup baik.

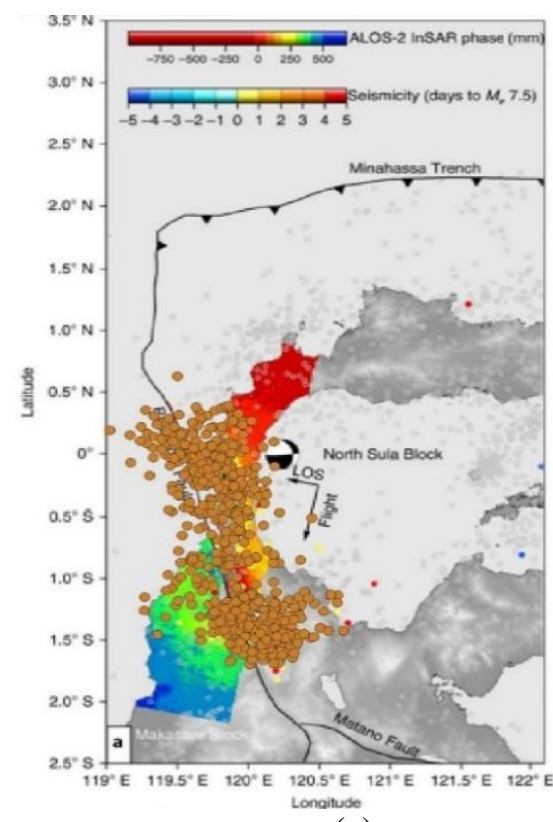

(a) 


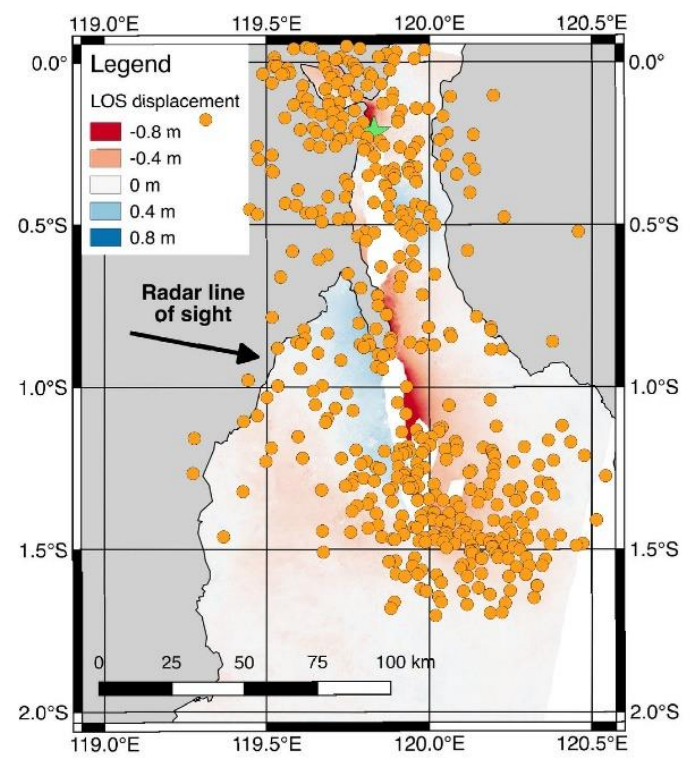

(b)

Gambar 8. Hasil validasi dengan pemetaan citra satelit (a) ALOS-2 mode ScanSAR dari Socquet dkk. (2019), dan (b) ALOS-2 PALSAR-2

\section{KESIMPULAN}

Dari hasil relokasi gempabumi Donggala menggunakan hypoRelocate dapat disimpulkan bahwa:

1. Episenter hasil relokasi memiliki hasil yang lebih mengumpul atau terfokus daripada posisi awal dan membentukkluster yang berwujud sebuah bidang dengan luas sekitar 250 $\mathrm{km} \times 85 \mathrm{~km}$.

2. Sebagian besar episenter setelah direlokasi bergeser dengan jarak 15-20 $\mathrm{km}$ dengan dengan pergeseran maksimum $30,76 \mathrm{~km}$ dan pergeseran minimum 435 meter. Perubahan kedalaman gempabumi dominan kurang dari $10 \mathrm{~km}$ dan perubahan kedalaman maksimal 25,56 km. Arah pergeseran episenter tersebar merata secara acak namun arah barat lebih sedikit dominan.

3. Relokasi menggunakan hypoRelocate menunjukkan peningkatan kualitas yang cukup baik dengan turunnya nilai total residual setelah relokasi

4. Hasil validasi relokasi hypoRelocate dengan peta citra satelit ALOS-2 mode ScanSAR ALOS-2 PALSAR-2 menunjukan bahwa hasil relokasi berada pada bidang sesar gempabumi.

\section{UCAPAN TERIMA KASIH}

Penulis mengucapkan terima kasih kepada BMKG untuk data katalog gempa dan atas akses data yang diberikan; Dr. Sun Li, Miao Zhang dan Lianxing Wen untuk program hypoRelocate; Wessel dan Smith untuk program GMT, dan Mas Yusuf Haidar Ali atas bantuan dan kerjasamanya.

\section{DAFTAR PUSTAKA}

Pusat Studi Gempa Nasional. 2017. Peta Sumber Dan Bahaya Gempa Indonesia tahun 2017. Bandung: Kementerian Pekerjaan Umum dan Perumahan Rakyat.

Long, H., \& Wen, L. 2012. Using repeated sources to quantitatively determine temporal change of medium properties: Theory and an example. Journal of Geophysical Research: Solid Earth, 117(9).

Waldhauser, F., \& Ellsworth, W. L. 2000. A Double-difference Earthquake location algorithm: Method and application to the Northern Hayward Fault, California. Bulletin of the Seismological Society of America, 90(6), 1353-1368.

Sun, L., Zhang, M., \& Wen, L. 2016. A new method for high-resolution event relocation and application to the aftershocks of Lushan Earthquake, China. Journal of Geophysical Research: Solid Earth, 121(4), 2539-2559.

Kurniawan. 2018. Relokasi Hiposenter Gempabumi Menggunakan hypoRelocate (Studi Kasus Gempabumi Pidie Jaya Tahun 2016 2017). Skripsi. Sekolah Tinggi Meteorologi Klimatologi dan Geofisika

Liang J H, Sun L, Liu J. 2018 A high precision relocation study of the Ms 7.0 Jiuzhaigou earthquake and the aftershocks occurred in 2017. Chinese J. Geophys, 2152-2162.

Aki, K. 1969. Analysis of the Seismik Coda of Local Earthquakes as Scattered Waves. Journal of Geophysical Research, 74(2), 615-631

Kirkpatrick, S., Gelatt, C. D., \& Vecchi, M. P. 1983. Optimization by Simulated Annealing. Science, 220(4598), 671680.

Kennett, B. \& Engdahl, E. 1991. Traveltimes for global earthquake location and phase 
identification, Geophys. J. Int., 105, 429-465

Socquet, A., Hollingsworth, J., Pathier, E., Bouchon, M. 2019. Evidence of supershear during the 2018 magnitude 7.5 Palu earthquake from space geodesy. Nature Geoscience 12 :192-199
ARIA Along-track Deformation Map of the M7.5 September 28, 2018 Sulawesi earthquake, Indonesia. (https://disasters.nasa.gov/sulawesiisland-indonesia-earthquake-andtsunami-2018/aria-along-trackdeformation-map-m75-september) 